\title{
Aesthetic Quality and Strength of Bioplastic Biocontainers at Different Substrate Volumetric Water Contents
}

\author{
Nicholas J. Flax, Christopher J. Currey ${ }^{1,2}$, Alexander G. Litvin, \\ and James A. Schrader \\ Department of Horticulture, Iowa State University, 106 Horticulture Hall, \\ Ames, IA 50011 \\ David Grewell \\ Department of Agricultural and Biosystems Engineering, Iowa State \\ University, 4356 Elings Hall, Ames, IA 50011
}

William R. Graves

Department of Horticulture, Iowa State University, 106 Horticulture Hall, Ames, IA 50011

Additional index words. biocomposite, geranium, new guinea impatiens, precision irrigation, soil moisture sensor, nonchemical growth control

\begin{abstract}
Various types of emerging bioplastic containers present a range of physical and chemical properties and can perform differently from one another in production environments. Container performance may be affected by substrate moisture content. We quantified the effects of bioplastic container type and substrate volumetric water content (VWC) on the aesthetic and mechanical strength properties of bioplastic containers and on plant growth. Seedlings of 'Divine Cherry Red' new guinea impatiens (Impatiens hawkeri W. Bull) and 'Pinot Premium Deep Red' zonal geranium (Pelargonium $\times$ hortorum L.H. Bailey) were transplanted into five types of 11.4-cm-diameter containers, four types made from bioplastics and one type made from petroleum-based plastic and used as a control. Plants were watered to container capacity at transplant, allowed to dry down to VWC thresholds of 0.20 or $0.40 \mathrm{~m}^{3} \cdot \mathrm{m}^{-3}$, and subsequently maintained at desired set points by using a precision irrigation system controlled by soil moisture sensors. Total volume of water applied per plant to new guinea impatiens was affected by VWC and not container type, whereas irrigation volume was affected by both for geranium. Growth index and shoot dry mass (SDM) of new guinea impatiens and geranium were affected by VWC. Container type affected growth index and SDM of geranium only. Water use efficiency (WUE) of both species was similar regardless of container type and VWC. Aesthetic quality varied based on VWC for only one container type, which was made from a blend that included soy-based bioplastic. Containers manufactured with polyhydroxyalkanoates (PHA) and dried distiller's grains and solubles (DDGS) or polylactic acid (PLA), soy polymer with adipic anhydride (SP.A), and a proprietary bio-based filler (BR) derived from modified DDGS were stronger when maintained at a lower $\mathrm{VWC}, 0.20 \mathrm{~m}^{3} \cdot \mathrm{m}^{-3}$. Our findings indicate that restricting irrigation to the minimum needed to achieve the desired crop growth is a viable strategy for sustaining aesthetic quality and strength of bioplastic containers manufactured with plant protein-based fillers such as SP.A and BR. Other bioplastic containers, such as those made of PLA-lignin biocomposite, show durability equal to that of petroleum-based plastic containers and maintain pristine appearance regardless of substrate VWC during production.
\end{abstract}

Annual bedding and garden plants are valued at $\approx \$ 2.56$ billion in the United States. and accounted for almost half (44\%) of the

Received for publication 13 Oct. 2017. Accepted for publication 30 Jan. 2018.

We gratefully acknowledge Peter Lawlor for greenhouse assistance, Brianna Keninger and Erica Schlichte for experiment setup and data collection assistance; Wagner Greenhouses for plant material and the USDA Specialty Crops Research Initiative and the National Institute of Food and Agriculture for funding.

${ }^{1}$ Assistant Professor

${ }^{2}$ Corresponding author. E-mail: ccurrey@iastate.edu. market value of floriculture crops sold in 2014 (\$5.87 billion; U.S. Department of Agriculture, 2015). Excluding plants produced in flats and hanging baskets, $\approx 70 \%$ (416 million of $\approx 600$ million units) of bedding plants were produced in containers less than 5 inches in diameter. These smallcontainer annuals are an economically important category among annual bedding plants. It is likely, however, that most of these units were produced in nonrenewable petroleum-based plastic containers, a practice that consumes large amounts of finite fossil fuel resources (Montalbo-Lomboy et al., 2016) and creates a waste disposal concern (Evans et al., 2010).
Petroleum-based plastic plant containers are easily manufactured in a variety of shapes and sizes (Evans and Hensley, 2004) and are inexpensive now (Hall et al., 2010). Intensive use of these containers creates copious persistent waste (Schrader, 2013). Biocontainers, manufactured from renewable, biobased materials, offer an alternative to container-crop producers that may be as or more sustainable than petroleum-based plastic containers (Koeser et al., 2014). Although fossil fuels are used in the manufacture, distribution, or both of all types of plant containers, large-scale use of biocontainers could become an effective means to greatly reduce persistent waste produced by the container-crops industry. Research demonstrates that high-quality potted and annual bedding plants can be produced in biocontainers (Kuehny et al., 2011; Lopez and Camberato, 2011). However, many commercially available biocontainers, particularly those made of bio-based fibers such as peat or coconut coir, are less durable than petroleum-based plastic pots, and their use can result in poor WUE during plant production (Conneway et al., 2015; Evans and Hensley, 2004; Evans et al., 2010; McCabe et al., 2014)

Bioplastic-based biocontainers are a newer biocontainer technology (Currey et al., 2013, 2014,2015 ). These containers are made from bioplastics, bioplastic blends, or biocomposites that are processed and formed on the same equipment used to make petroleumbased containers, and, therefore, are very similar in form and function to those of conventional petroleum-based pots, yet are inherently more sustainable (MontalboLomboy et al., 2016). Although few are fully commercialized, bioplastic plant containers have yielded positive results with respect to plant quality, and container appearance and durability of many bioplastic container types are similar to those of petroleum-based plastic containers (Flax et al., 2017; Kratsch et al., 2015; McCabe et al., 2016; Schrader et al., 2015). However, certain bioplastic container types, particularly those designed to provide bio-based fertilizer nutrients (Schrader et al., 2013) or to biodegrade after use, exhibited algal growth on the container surface, diminished aesthetic quality, and poorer grower-perceived durability at the end of crop production when compared with petroleum-based plastic containers (Flax et al., 2017). Algal growth on surfaces and variation in container strength of other types of biocontainers (such as peat fiber containers) have been observed by other researchers (Conneway et al., 2015; Evans and Karcher, 2004; Evans et al., 2010).

Flax et al. (2017) postulated that moisture management during plant production affected the appearance of certain bioplastic containers, and proliferation of algae on the surface of peat-based biocontainers was attributed to irrigation practices and absorption of water by the containers (Evans et al., 2010). Research shows that plant growth can be controlled without compromising 
plant quality by reducing substrate VWC (Alem et al., 2015; Bayer et al., 2013). Although we have found no reports quantifying the effect of VWC on bioplastic container appearance and strength, commercial growers have reported potential injury liability and product loss due to easily broken biocontainers (Koeser et al., 2013; Nambuthiri et al., 2015). We contend that reducing substrate VWC may also reduce algal growth improve postproduction appearance and strength of certain bioplastic biocontainers. Therefore, our objectives were to quantify the effect of moisture management practices on the aesthetic quality of four distinct bioplastic biocontainer types and elucidate any effects that moisture management may have on bioplastic container strength.

\section{Materials and Methods}

Container types. Five types of 11.4-cmdiameter injection-molded containers were evaluated (Table 1), including four bioplastic biocontainers $\left(655 \mathrm{~mL}\right.$ volume; VistaTek ${ }^{\circledR}$, Stillwater, MN) and a petroleum-based plastic (control) container $(655 \mathrm{~mL}$ volume; ITML, Middlefield, OH). Bioplastic containers represented containers classified as durable, compostable, or biodegradable in soil (Schrader et al., 2015). Selections were based on both high and low ratings for container quality reported by Flax et al. (2017), in which containers manufactured with SP.A or PHA-DDGS received lower quality ratings than other container types, whereas PLA-lignin containers received ratings comparable with petroleum-based plastic controls.

Greenhouse culture and moisture treatments. Seedlings of new guinea impatiens and zonal geranium were transplanted individually into containers filled with soilless substrate composed of (by volume) $80 \%$ canadian sphagnum peatmoss and $20 \%$ perlite (Sunshine ${ }^{\circledR}$ LB-2; Sun Gro Horticulture, Inc., Agawam, MA) on 20 Apr. and 19 Aug., respectively. The substrate was amended with $2.4 \mathrm{~kg} \cdot \mathrm{m}^{-3}$ (new guinea impatiens; Haver and Schuch, 1996) and $4.2 \mathrm{~kg} \cdot \mathrm{m}^{-3}$ (geraniums; Krug et al., 2014) controlled release fertilizer [Florikan Plus $16.0 \mathrm{~N}-2.2 \mathrm{P}-9.1 \mathrm{~K}$ with a 90 -d release period (Florikan ESA LLC, Sarasota, FL)] to ensure that equal total amounts of mineral nutrients were provided across moisture treatments. Plant containers were filled by hand and placed into 10-cell petroleumplastic shuttle trays; two trays of each container type were placed adjacent to one another on the greenhouse bench to create $4 \times 5$-container experimental units.

An automated irrigation system controlled by soil moisture sensors was used to maintain VWC treatments (Nemali and van Iersel, 2006). Drip irrigation stakes attached to $1.9 \mathrm{~L} \cdot \mathrm{h}^{-1}$ pressure-compensating emitters (Netafim USA, Fresno, CA) were inserted into the substrate, and plants were overheadirrigated to container capacity with clear tempered water. After overhead irrigation, capacitance moisture sensors (EC-5;
Decagon Devices Inc., Pullman, WA) were inserted into the substrate of the two innermost plant containers within each experimental unit. Sensors connected to a multiplexer (AM16/32B; Campbell Scientific, Logan, UT) cycling measurement readings to a data logger (CR1000; Campbell Scientific) calculated VWC using a manufacturerprovided calibration curve specific to soilless peat-based substrates. Substrate VWC decreased to thresholds of 0.40 or $0.20 \mathrm{~m}^{3} \cdot \mathrm{m}^{-3}$ over a period of $\approx 7 \mathrm{~d}$, and the desired VWC was maintained by the data logger and a series of solenoid valves (Orbit Irrigation Products, Inc., Bountiful, UT) connected to polyethylene tubing with drip emitters. Irrigation events occurred on a need basis when measured VWC fell below the threshold for each experimental unit. The data logger program was executed every $10 \mathrm{~min}$ to determine need. Solenoid valves corresponding to each experimental unit were controlled by a relay driver (SDMCD16AC controller; Campbell Scientific) connected to the data logger. Valves opened for $10 \mathrm{~s}$ during each irrigation event, providing $6.2 \mathrm{~mL}$ of clear water per plant per event.

Plants were grown for 7 or 6 weeks (new guinea impatiens and geranium, respectively) in a glass-glazed greenhouse with retractable shade curtains, fog cooling, radiant hot water heating, and 1000-W high-pressure sodium lamps that operated between 0600 and 2200 HR to provide a supplemental photosynthetic photon flux $(P P F)$ of $\approx 176 \pm 12 \mu \mathrm{mol} \cdot \mathrm{m}^{-2} \cdot \mathrm{s}^{-1}$ at plant height [measured by a quantum sensor (LI-190 SB; LI-COR Biosciences, Lincoln, NE)] and maintain a target daily light integral (DLI) of $\approx 15 \mathrm{~mol} \cdot \mathrm{m}^{-2} \cdot \mathrm{d}^{-1}$. Average daily air temperature (ADT) was recorded by temperature probes (41342; R.M. Young Company, Traverse City, MI) housed within actively aspirated radiation shields (43502; R.M. Young Company). Quantum sensors and temperature probes were connected to a data logger (CR1000; Campbell Scientific) that measured air temperature and $P P F$ every $15 \mathrm{~s}$ and logged averages every $30 \mathrm{~min}$ (Table 2 ); the average DLI was $\approx 15$ for both taxa and the ADT for new guinea impatiens and zonal geranium were 23.6 and $24.7^{\circ} \mathrm{C}$, respectively. Greenhouse temperature set points were maintained by an environment control computer (Titan; ARGUS Control Systems, Surrey, BC, Canada).

Data collection and calculations. Plant growth data were collected 7 (new guinea impatiens) and 6 weeks (geranium) after transplant and included plant height from the substrate to the tallest growing point, widest diameter (diameter 1), and width $90^{\circ}$ from the widest diameter (diameter 2); growth index was calculated for each plant (growth index $=\{$ plant height $+[$ (diameter $1+$ diameter 2)/2]\}/2). Data were only collected from the six innermost plants in each experimental unit. This was done to exclude edge effects from the measured data

Table 1. Parent materials of 11.4-cm-diameter bioplastic plant containers and a petroleum-based plastic (control) container used to produce new guinea impatiens (Impatiens hawkeri W. Bull 'Divine Cherry Red') and zonal geranium (Pelargonium $\times$ hortorum L.H. Bailey 'Pinto Premium Deep Red') in a soil moisture sensor-controlled irrigation system were polylactic acid (PLA; commercial bioplastic), lignin powder, soy polymer with adipic anhydride (SP.A), BioRes (BR; a refined coproduct of corn ethanol production), polyhydroxyalkanoates (PHA; commercial bioplastic), dried distiller's grains and solubles (DDGS; a coproduct of corn ethanol production), and coloring agents. Container types were selected based on quality rating data reported by Flax et al. (2017).

\begin{tabular}{lcll}
\hline Container type $^{\mathrm{z}}$ & $\begin{array}{c}\text { Proportions of materials } \\
(\% \text { by mass, respectively) }\end{array}$ & Fertilizer effect $^{\mathrm{y}}$ & Container degradability $^{\mathrm{x}}$ \\
\hline PLA-lignin & $90 / 10$ & No & Durable \\
PLA-SP.A-BR & $50 / 30 / 20$ & Yes & Compostable \\
PLA-SP.A & $60 / 40$ & Yes & Compostable \\
PHA-DDGS & $80 / 20$ & No & Biodegradable \\
Petroleum-based plastic & 100 & No & Nondegradable \\
\hline
\end{tabular}

${ }^{\mathrm{z}}$ Container types (excluding petroleum-based plastic) are blends of different ratios of bioplastic and biocomposite materials.

${ }^{\mathrm{y}}$ Containers manufactured with SP.A release plant-available mineral nutrients as containers degrade (Schrader et al., 2013).

${ }^{\mathrm{x}}$ Degradability of bioplastic-based biocontainers as characterized by Schrader et al. (2015); biodegradable = biodegradable in soil within 1-2 years (these are also compostable); compostable = nondegradable in soil within 1-2 years, but degradable by composting; durable = durable containers that improve on sustainability while requiring little or no change in cultural practices; nondegradable $=$ noncompostable and nonbiodegradable.

Table 2. Daily light integral (DLI), average daily air temperature (ADT), and average day (DT) and night $(\mathrm{NT})$ temperatures $( \pm \mathrm{SD})$ for new guinea impatiens (Impatiens hawkeri W. Bull 'Divine Cherry Red') and zonal geranium (Pelargonium $\times$ hortorum L.H. Bailey 'Pinto Premium Deep Red') grown in four types of 11.4-cm-diameter bioplastic biocontainers and a petroleum-based plastic (control) container filled with soilless substrate amended with $2.4 \mathrm{~kg} \cdot \mathrm{m}^{-3}$ (new guinea impatiens) or $4.2 \mathrm{~kg} \cdot \mathrm{m}^{-3}$ (geranium) controlled release fertilizer and maintained at 0.20 or $0.40 \mathrm{~m}^{3} \cdot \mathrm{m}^{-3}$ substrate volumetric water content.

\begin{tabular}{lcccc}
\hline Species & DLI $\left(\mathrm{mol} \cdot \mathrm{m}^{-2} \cdot \mathrm{d}^{-1}\right) \pm \mathrm{sD}$ & $\mathrm{ADT}\left({ }^{\circ} \mathrm{C}\right)^{\mathrm{z}} \pm \mathrm{SD}$ & $\mathrm{DT}\left({ }^{\circ} \mathrm{C}\right) \pm \mathrm{sD}$ & $\mathrm{NT}\left({ }^{\circ} \mathrm{C}\right) \pm \mathrm{SD}$ \\
\hline New guinea impatiens & $15.2 \pm 2.3$ & $23.6 \pm 1.2$ & $25.2 \pm 1.3$ & $20.9 \pm 0.9$ \\
Geranium & $15.0 \pm 2.6$ & $24.7 \pm 1.2$ & $26.1 \pm 1.3$ & $21.8 \pm 1.7$ \\
\hline
\end{tabular}

${ }^{\mathrm{z}_{\circ}} \mathrm{C}=\left({ }^{\circ} \mathrm{F} \times 1.8\right)+32$. 
and to simulate growth among a larger group of plants. Plants were harvested at the substrate surface and dried, and SDM was measured. Volume of water applied is reported as total volume of water applied to plants after VWC thresholds were reached [irrigation volume $(\mathrm{L})=6.2 \mathrm{~mL}$ water $\times$ no. of irrigation events] and automated irrigation began; water loss due to plant transpiration and substrate surface evaporation was not accounted for. Water use efficiency $\{$ WUE $=$ $[\mathrm{SDM}(\mathrm{g}) /$ irrigation volume (L)] $\}$ was calculated; for our purposes, SDM used in our calculations does not account for dry mass accumulation before planting containers; thus, how we define WUE may not reflect other researchers' definitions. Following shoot harvest, two experienced horticulturists rated container aesthetic quality on a scale of 1 to 5 ( $n=6$ per container type per moisture level; 1 = lowest quality, 5 = highest quality), as per container rating criteria described by Flax et al. (2017). Container sides facing toward and away from the shuttle tray interior were rated separately based on observations from previous research using the same bioplastic containers, and ratings of the two sides of each container were averaged. For the six plants harvested from each replication, substrate was removed from containers, vertical and horizontal crush strength (three containers for each measurement) was measured using a universal testing machine (Instron 5569; Instron ${ }^{\circledR}$, Norwood, MA), and vertical and horizontal compression required for a crack at least $2.5 \mathrm{~cm}$ in length to form in containers was recorded. Crush strength tests were conducted immediately after the plants were harvested and the containers were not oven-dried; therefore, we will refer to crush strength as "wet strength."

Experimental design and statistical analyses. We used a two-way factorial randomized complete block design with container type (five levels) and substrate VWC (two levels) as factors. Treatments were replicated in time $(n=3)$ in a common greenhouse environment. Analyses of variance were performed using PROC GLM of SAS version 9.4 (SAS Institute, Inc., Cary, NC), and mean separations were performed using Tukey's honestly significant difference test at $P \leq 0.05$.

\section{Results}

New guinea impatiens. Substrate VWC was maintained at 0.20 or $0.40 \mathrm{~m}^{3} \cdot \mathrm{m}^{-3} \mathrm{VWC}$ (Fig. 1). Irrigation volume was affected by VWC only (Table 3). Plants maintained at $0.20 \mathrm{~m}^{3} \cdot \mathrm{m}^{-3}$ VWC received $31 \%$ less total water than plants at $0.40 \mathrm{~m}^{3} \cdot \mathrm{m}^{-3}$ from the time that VWC set points were reached until the conclusion of the experiment (Table 4).

Growth index was affected by VWC only (Table 3). The growth index of plants maintained at $0.20 \mathrm{~m}^{3} \cdot \mathrm{m}^{-3} \mathrm{VWC}$ was $14 \%$ less than those grown at $0.40 \mathrm{~m}^{3} \cdot \mathrm{m}^{-3}$ (Table 4). Similarly, plants in the $0.20 \mathrm{~m}^{3} \cdot \mathrm{m}^{-3}$ treatment had $25 \%$ less SDM than plants at $0.40 \mathrm{~m}^{3} \cdot \mathrm{m}^{-3}$ VWC (Table 4). Alternatively, container type

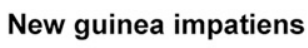

Zonal geraniums

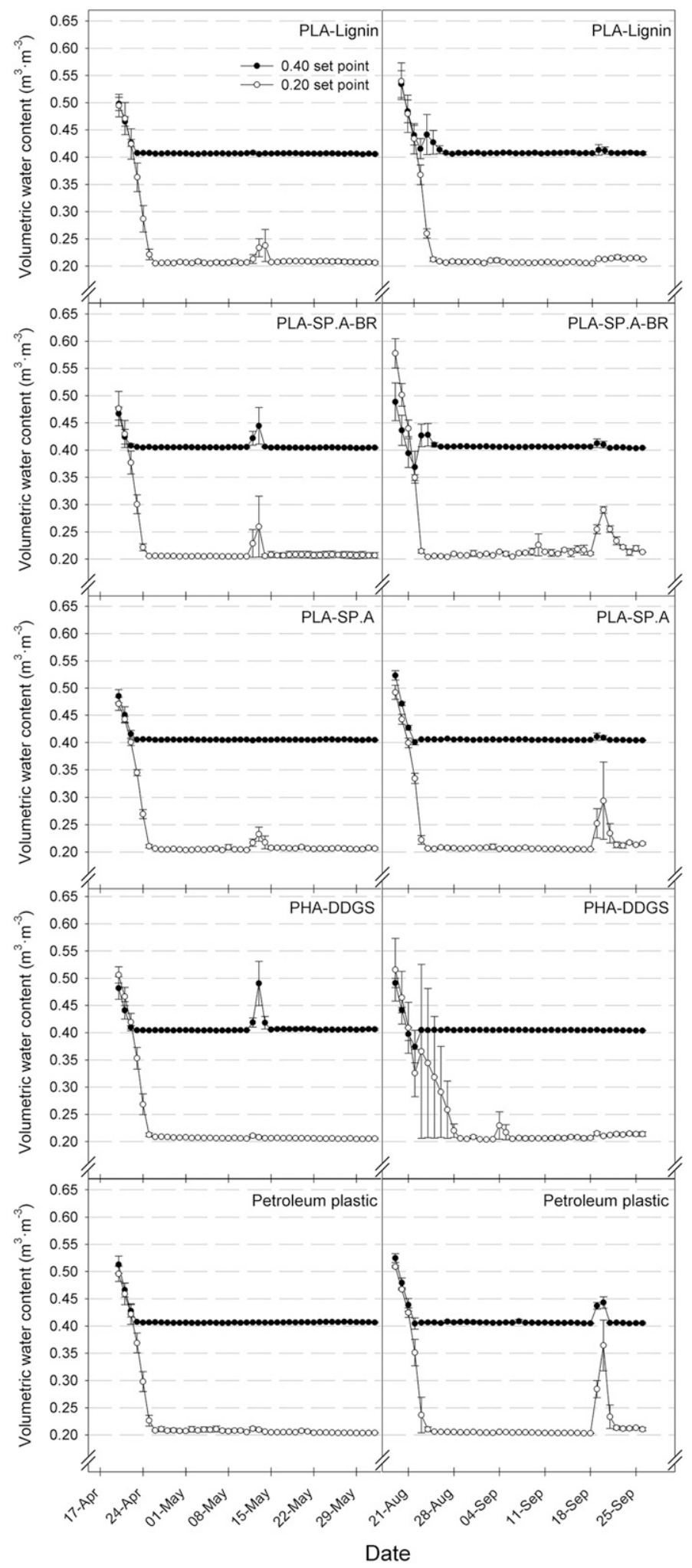

Fig. 1. Substrate volumetric water content (VWC) for new guinea impatiens (Impatiens hawkeri W. Bull 'Divine Cherry Red') and geranium (Pelargonium $\times$ hortorum L.H. Bailey 'Pinto Premium Deep Red') grown in four types of 11.4-cm-diameter bioplastic biocontainers comprising polylactic acid (PLA)-lignin, PLA-soy polymer with adipic anhydride (SP.A)-a proprietary bio-based filler derived from dried distiller's grains and solubles (BR), PLA-SP.A, or polyhydroxyalkanoates (PHA)-dried distiller's grains and solubles (DDGS) or a petroleumbased plastic (control) container filled with soilless substrate amended with $2.4 \mathrm{~kg} \cdot \mathrm{m}^{-3}$ (new guinea impatiens) or $4.2 \mathrm{~kg} \cdot \mathrm{m}^{-3}$ (geranium) controlled release fertilizer, and maintained at 0.20 or $0.40 \mathrm{~m}^{3} \cdot \mathrm{m}^{-3}$ substrate VWC.

affected the SDM of new guinea impatiens (Table 3). Plants grown in PLA-SP.A containers accumulated more SDM than plants in all other container treatments except those in PLA-SP.A-BR containers (Table 5). Plants grown in PHA-DDGS containers were $30 \%$ 
smaller than those grown in PLA-SP.A containers and had similar SDM to plants in other container types (Table 5). WUE was unaffected by VWC or container type (Table 3); WUE ranged from 11.9 to 12.0 g. $\mathrm{L}^{-1}$ pooled across container types and

Volumetric water content and container type interacted to affect container aesthetic ratings (Table 3). Within container type, aesthetic ratings of PLA-SP.A-BR containers maintained at $0.20 \mathrm{~m}^{3} \cdot \mathrm{m}^{-3} \mathrm{VWC}$ were $59 \%$ higher than that of those maintained at $0.40 \mathrm{~m}^{3} \cdot \mathrm{m}^{-3}$ (Table 6), whereas PHA-DDGS

Table 3. Analyses of variance for the effects of substrate volumetric water content (VWC) (V) and container type (C) on total irrigation volume, growth index, shoot dry mass $(\mathrm{SDM})$, water use efficiency $\{$ WUE $=[\mathrm{SDM}$ (g)/volume water applied (L)]\}, aesthetic quality ratings of container sidewalls facing toward (Side A) and away from (Side B) shuttle trays, and container vertical and horizontal wet strength (MPa) for containers used to grow new guinea impatiens (Impatiens hawkeri W. Bull 'Divine Cherry Red') and zonal geranium (Pelargonium ×hortorum L.H. Bailey 'Pinto Premium Deep Red'). Four types of 11.4-cmdiameter bioplastic biocontainers and a petroleumbased plastic (control) container filled with soilless substrate were used and substrate was maintained at 0.20 or $0.40 \mathrm{~m}^{3} \cdot \mathrm{m}^{-3}$ substrate VWC.

\begin{tabular}{lccc}
\hline Parameter & $\mathrm{V}$ & $\mathrm{C}$ & $\mathrm{V} \times \mathrm{C}$ \\
\hline New guinea impatiens & & & \\
Irrigation volume & $* *$ & NS & NS \\
Growth index & $* * *$ & NS & NS \\
SDM & $* * *$ & $*$ & NS \\
WUE & NS & NS & NS \\
Aesthetic rating & $* * *$ & $* * *$ & $* * *$ \\
$\quad$ Vertical wet strength & $* *$ & $* * *$ & NS \\
$\quad$ Vertical compression to & NS & $* * *$ & $* *$ \\
$\quad$ crack & & & \\
Horizontal wet strength & NS & $* * *$ & NS \\
Horizontal compression & NS & $* * *$ & NS \\
$\quad$ to crack & & & \\
Geranium & & & \\
Irrigation volume & $* * *$ & $*$ & NS \\
Growth index & $* * *$ & $* * *$ & $* *$ \\
SDM & $* * *$ & $* * *$ & $* *$ \\
WUE & NS & NS & NS \\
Aesthetic rating & $* *$ & $* * *$ & $* * *$ \\
$\quad$ Vertical wet strength & $* * *$ & $* * *$ & $* *$ \\
$\quad$ Vertical compression to & $* * *$ & $* * *$ & $* *$ \\
$\quad$ crack & & & \\
Horizontal wet strength & NS & $* * *$ & NS \\
Horizontal compression & NS & $* * *$ & NS \\
$\quad$ to crack & & & \\
\hline
\end{tabular}

Ns, $*, * *, * * *$ Nonsignificant or significant at $P \leq$ $0.05,0.01$, or 0.001 , respectively. within VWC.

containers were rated similarly at both VWCs. Alternatively, PLA-lignin and PHA-DDGS containers were rated similarly to petroleum-based plastic containers at $0.20 \mathrm{~m}^{3} \cdot \mathrm{m}^{-3} \mathrm{VWC}$, but PHA-DDGS containers were rated $8 \%$ lower than PLAlignin and petroleum-plastic controls at $0.40 \mathrm{~m}^{3} \cdot \mathrm{m}^{-3}$ (Table 6). Both PLA-lignin and petroleum-plastic control containers received mean ratings of 5.0 (Table 6).

Vertical wet strength was affected by VWC and by container type, whereas horizontal strength was only affected by container type (Table 3 ). Pooled across container types, containers maintained at $0.20 \mathrm{~m}^{3} \cdot \mathrm{m}^{-3}$ were $12 \%$ stronger than those at $0.40 \mathrm{~m}^{3} \cdot \mathrm{m}^{-3}$ VWC (Table 4). Containers made of PLAlignin had the greatest vertical wet strength, followed by PHA-DDGS containers (Table 5). Conversely, PLA-SP.A-BR containers had the lowest vertical wet strength and were $59 \%$ to $93 \%$ weaker in vertical strength than all other container types (Table 5). The vertical compression required to crack the containers was affected by the interaction of VWC and container type (Table 3). Biocontainers made of PLA-SP.A-BR, PLA-SP.A, and PHADDGS with VWC maintained at $0.20 \mathrm{~m}^{3} \cdot \mathrm{m}^{-3}$ broke $23 \%, 14 \%$, or $22 \%$ sooner, respectively, than when VWC was maintained at $0.40 \mathrm{~m}^{3} \cdot \mathrm{m}^{-3}$ (Table 6). All bioplastic containers exhibited cracks greater than $2.5 \mathrm{~cm}$ in length.

Horizontal wet strength and horizontal compression required to crack containers were only affected by container type (Table 3). Horizontal strength was greatest for PLA-lignin containers $(0.34 \mathrm{MPa})$ and weakest for PLA-SP.A-BR containers (0.01 $\mathrm{MPa}$; Table 5). Alternatively, PHA-DDGS containers required the greatest amount of compression distance to crack $(43.5 \mathrm{~mm})$ of the biocontainers, whereas PLA-SP.A-BR containers cracked after $25.2 \mathrm{~mm}$ of compression. All PLA-lignin, PLA-SP.A-BR, and PLA-SP.A containers exhibited cracks at least $2.5 \mathrm{~cm}$ in length. The two PHADDGS containers maintained at $0.20 \mathrm{~m}^{3} \cdot \mathrm{m}^{-3}$ VWC did not break, whereas all PHA-DDGS containers in the $0.40 \mathrm{~m}^{3} \cdot \mathrm{m}^{-3}$ treatment group cracked.

Geranium. The substrate VWC was maintained at 0.20 or $0.40 \mathrm{~m}^{3} \cdot \mathrm{m}^{-3}$ (Fig. 1). The irrigation volume was affected by VWC and by container type (Table 3 ). Plants maintained at $0.20 \mathrm{~m}^{3} \cdot \mathrm{m}^{-3} \mathrm{VWC}$ received $27 \%$ less total water than plants at $0.40 \mathrm{~m}^{3} \cdot \mathrm{m}^{-3}$ from the time that VWC set points were reached until the conclusion of the experiment

Table 4. Total irrigation volume (per plant), growth index, shoot dry mass (SDM), and container vertical wet strength for new guinea impatiens (Impatiens hawkeri W. Bull 'Divine Cherry Red') grown in four types of 11.4-cm-diameter bioplastic plant containers and a petroleum-based plastic (control) container filled with soilless substrate amended with $2.4 \mathrm{~kg} \cdot \mathrm{m}^{-3}$ controlled release fertilizer and maintained at 0.20 or $0.40 \mathrm{~m}^{3} \cdot \mathrm{m}^{-3}$ substrate volumetric water content (VWC). Data are pooled across container type for each VWC.

\begin{tabular}{lcccc}
\hline VWC $\left(\mathrm{m}^{3} \cdot \mathrm{m}^{-3}\right)$ & Irrigation vol $(\mathrm{L})$ & Growth index & SDM $(\mathrm{g})$ & Vertical wet strength $(\mathrm{MPa})$ \\
\hline 0.20 & 1.6 & 25.5 & 19.1 & 0.80 \\
0.40 & 2.3 & 29.7 & 25.4 & 0.74 \\
Significance & $* *$ & $* * *$ & $* * *$ & $* *$ \\
\hline
\end{tabular}

${ }^{\mathrm{z}}$ Growth index $=\{$ plant height $+[($ diameter $1+$ diameter 2$) / 2]\} / 2$.

$* *, * * *$ Different by Tukey's honestly significant difference test at $P \leq 0.01$ or 0.001 , respectively.
(Table 7). Plants grown in PLA-SP.A-BR containers received the least water $(1.23 \mathrm{~L})$, whereas those grown in PHA-DDGS containers received the most (1.94 L; Table 8).

Volumetric water content and container type interacted to affect growth index (Table 3). For example, plants grown in PLA-SP.A-BR containers at $0.20 \mathrm{~m}^{3} \cdot \mathrm{m}^{-3}$ VWC were $43 \%$ smaller than the ones grown at $0.40 \mathrm{~m}^{3} \cdot \mathrm{m}^{-3}$, whereas plants grown in PLA-SP.A containers were similar at both VWCs (Table 9). Alternatively, all plants maintained at $0.40 \mathrm{~m}^{3} \cdot \mathrm{m}^{-3} \mathrm{VWC}$ were similar across container types, whereas those grown in PLA-SP.A-BR containers were smallest among plants maintained at $0.20 \mathrm{~m}^{3} \cdot \mathrm{m}^{-3}$ VWC. Differences among the SDM of plants were consistent with those observed for the growth index (Tables 3 and 9). The WUE was unaffected by VWC or container type for geraniums, as it was with new guinea impatiens (Table 3), and WUE ranged from 14.2 to $14.7 \mathrm{~g} \cdot \mathrm{L}^{-1}$ for geranium pooled across container types and within VWC treatments.

Container type interacted with VWC to affect container aesthetic ratings (Table 3 ). Within the $0.20 \mathrm{~m}^{3} \cdot \mathrm{m}^{-3} \mathrm{VWC}$ treatment, PHA-DDGS containers were rated similarly to PLA-SP.A containers, but were rated $29 \%$ higher than PLA-SP.A containers when maintained at $0.40 \mathrm{~m}^{3} \cdot \mathrm{m}^{-3} \mathrm{VWC}$ (Table 9). Alternately, PHA-DDGS containers were rated similarly at both VWC set points, whereas PLA-SP.A-BR containers were rated lower at $0.40 \mathrm{~m}^{3} \cdot \mathrm{m}^{-3}$ than at $0.20 \mathrm{~m}^{3} \cdot \mathrm{m}^{-3}$. Similar to the results with new guinea impatiens, ratings were identical for containers made of PLA-lignin and the petroleumplastic control, with each receiving mean ratings of 5 , the highest ratings possible (Table 6).

Volumetric water content and container type interacted to affect vertical wet strength and compression required to crack containers (Table 3). The strength of PHA-DDGS containers and petroleum-plastic containers were similar at $0.20 \mathrm{~m}^{3} \cdot \mathrm{m}^{-3} \mathrm{VWC}$ but differed at $0.40 \mathrm{~m}^{3} \cdot \mathrm{m}^{-3}$. Alternatively, PHADDGS containers were $33 \%$ stronger at $0.20 \mathrm{~m}^{3} \cdot \mathrm{m}^{-3}$ than $0.40 \mathrm{~m}^{3} \cdot \mathrm{m}^{-3} \mathrm{VWC}$, whereas petroleum-plastic containers did not differ between VWCs (Table 9). PLA-lignin, PLA-SP.A, and petroleum-plastic containers were unaffected by the irrigation treatment level (Table 9). Vertical compression required to crack PLA-lignin and PHA-DDGS containers was similar at $0.20 \mathrm{~m}^{3} \cdot \mathrm{m}^{-3}$ but different at $0.40 \mathrm{~m}^{3} \cdot \mathrm{m}^{-3}$ (Table 9). Within container type, PHA-DDGS containers withstood $46 \%$ more compression before breaking when maintained at $0.20 \mathrm{~m}^{3} \cdot \mathrm{m}^{-3}$, compared with $0.40 \mathrm{~m}^{3} \cdot \mathrm{m}^{-3}$, whereas compression required to break other container types was unaffected by VWC (Table 9). All bioplastic containers exhibited cracks greater than $2.5 \mathrm{~cm}$ in length.

Horizontal wet strength and compression required to crack containers was affected by container type (Table 3). Much like the results when containers were used to grow 
Table 5. Shoot dry mass (SDM), container vertical and horizontal wet strength, and horizontal compression required to crack containers used to grow new guinea impatiens (Impatiens hawkeri W. Bull 'Divine Cherry Red') grown in four types of 11.4-cm-diameter bioplastic plant containers and a petroleumbased plastic (control) container filled soilless substrate amended with $2.4 \mathrm{~kg} \cdot \mathrm{m}^{-3}$ controlled release fertilizer, and maintained at 0.20 or $0.40 \mathrm{~m}^{3} \cdot \mathrm{m}^{-3}$ substrate volumetric water content (VWC). Data are pooled across VWC for each container type.

\begin{tabular}{|c|c|c|c|c|}
\hline \multirow[b]{2}{*}{ Container type $\mathrm{z}^{\mathrm{z}}$} & \multirow[b]{2}{*}{$\operatorname{SDM}(g)$} & \multicolumn{2}{|c|}{ Wet strength $(\mathrm{MPa})$} & \multirow{2}{*}{$\begin{array}{c}\text { Horizontal compression } \\
\text { to crack (mm) }\end{array}$} \\
\hline & & Vertical & Horizontal & \\
\hline$\overline{\text { PLA-lignin }}$ & $21.1 \mathrm{~b}^{\mathrm{y}}$ & $2.24 \mathrm{a}$ & $0.34 \mathrm{a}$ & $37.3 \mathrm{~b}$ \\
\hline PLA-SP.A-BR & $22.5 \mathrm{ab}$ & $0.16 \mathrm{e}$ & $0.01 \mathrm{c}$ & $25.2 \mathrm{c}$ \\
\hline PLA-SP.A & $26.7 \mathrm{a}$ & $0.46 \mathrm{c}$ & $0.08 \mathrm{bc}$ & $33.7 \mathrm{~b}$ \\
\hline PHA-DDGS & $18.7 \mathrm{~b}$ & $0.57 \mathrm{~b}$ & $0.15 \mathrm{~b}$ & $43.5 \mathrm{a}$ \\
\hline Petroleum-based plastic & $21.7 \mathrm{~b}$ & $0.39 \mathrm{~d}$ & $0.13 \mathrm{~b}$ & $\underline{x}^{x}$ \\
\hline
\end{tabular}

${ }^{\mathrm{z}}$ Container types are blends of different ratios of bioplastic and biocomposite materials; PLA = polylactic acid; SP.A = soy polymer with adipic anhydride; $\mathrm{BR}=$ a proprietary bio-based filler derived from dried distiller's grains and solubles; PHA = polyhydroxyalkanoates; DDGS = dried distiller's grains and solubles.

${ }^{\mathrm{y}}$ Means within columns that share letters are similar by Tukey's honestly significant difference test at $P \leq$ 0.05 .

${ }^{\mathrm{x}}$ Petroleum-based plastic containers did not crack.

Table 6. Aesthetic quality ratings and vertical compression required to crack containers used to grow new guinea impatiens (Impatiens hawkeri W. Bull 'Divine Cherry Red') grown in four types of 11.4-cm-diameter bioplastic plant containers and a petroleum-based plastic (control) container filled soilless substrate amended with $2.4 \mathrm{~kg} \cdot \mathrm{m}^{-3}$ controlled release fertilizer, and maintained at 0.20 or $0.40 \mathrm{~m}^{3} \cdot \mathrm{m}^{-3}$ substrate volumetric water content (VWC).

\begin{tabular}{lccc}
\hline & \multicolumn{3}{c}{ VWC $\left(\mathrm{m}^{3} \cdot \mathrm{m}^{-3}\right)$} \\
\cline { 2 - 4 } Container type $^{\mathrm{z}}$ & 0.20 & 0.40 & Significance $^{\mathrm{y}}$ \\
\hline Aesthetic rating (1 to $5 \mathrm{scale}^{\mathrm{x}}$ & & \\
PLA-lignin & $5.0 \mathrm{a}^{\mathrm{w}}$ & $5.0 \mathrm{a}$ & $\mathrm{NS}$ \\
PLA-SP.A-BR & $3.0 \mathrm{c}$ & $1.4 \mathrm{~d}$ & $* *$ \\
PLA-SP.A & $3.8 \mathrm{~b}$ & $3.0 \mathrm{c}$ & $\mathrm{NS}$ \\
PHA-DDGS & $4.7 \mathrm{a}$ & $4.6 \mathrm{~b}$ & $\mathrm{NS}$ \\
Petroleum-based & $5.0 \mathrm{a}$ & $5.0 \mathrm{a}$ & $\mathrm{NS}$ \\
plastic & & & \\
Vertical compression to crack $(\mathrm{mm})$ & \\
PLA-lignin & $15.6 \mathrm{a}$ & $18.2 \mathrm{a}$ & $\mathrm{NS}$ \\
PLA-SP.A-BR & $5.9 \mathrm{~d}$ & $4.0 \mathrm{~d}$ & $*$ \\
PLA-SP.A & $7.6 \mathrm{c}$ & $6.6 \mathrm{c}$ & $*$ \\
PHA-DDGS & $13.3 \mathrm{~b}$ & $10.5 \mathrm{~b}$ & $*$ \\
Petroleum-based & $-{ }^{\mathrm{w}}$ & - & - \\
plastic & & & \\
\hline
\end{tabular}

${ }^{\mathrm{z}}$ Container types are blends of different ratios of bioplastic and biocomposite materials; PLA = polylactic acid; SP.A = soy polymer with adipic anhydride; $\mathrm{BR}=$ a proprietary bio-based filler derived from dried distiller's grains and solubles; PHA = polyhydroxyalkanoates; DDGS = dried distiller's grains and solubles.

${ }^{\mathrm{y}}$ Significance of differences among rows by Tukey's honestly significant difference test.

${ }^{\mathrm{x}}$ Ratings are on a 1 to 5 Likert scale; $1=$ worst quality, 2 = below average quality, $3=$ average quality, $4=$ above average quality, $5=$ best quality. ${ }^{\mathrm{w}}$ Means within columns that share letters are similar by Tukey's honestly significant difference test at $P \leq 0.05$.

Ns, $*, * *$ Nonsignificant or significant at $P \leq 0.05$ or 0.01 , respectively.

new guinea impatiens, PLA-lignin containers were the strongest $(0.33 \mathrm{MPa})$, and PLA-SP.A-BR containers were weakest (0.01 MPa; Table 8). Horizontal compression required to crack biocontainers was greatest for PLA-lignin and PHA-DDGS containers (38.8 and $42.1 \mathrm{~mm}$, respectively) and lowest for PLA-SP.A-BR containers $(25.7 \mathrm{~mm}$; Table 8). All PLA-lignin, PLA-SP.A-BR, and
Table 7. Total irrigation volume (per plant) applied to zonal geranium (Pelargonium $\times$ hortorum L.H. Bailey 'Pinto Premium Deep Red') grown in four types of 11.4-cm-diameter bioplastic plant containers and petroleum-plastic (control) filled with soilless substrate amended with $4.2 \mathrm{~kg} \cdot \mathrm{m}^{-3}$ controlled release fertilizer, and maintained at 0.20 or $0.40 \mathrm{~m}^{-3} \cdot \mathrm{m}^{-3} \mathrm{sub}-$ strate volumetric water content (VWC). Data were pooled across container type for each VWC.

\begin{tabular}{lc}
\hline VWC $\left(\mathrm{m}^{-3} \cdot \mathrm{m}^{-3}\right)$ & Irrigation vol $(\mathrm{L})$ \\
\hline 0.20 & $1.34 \mathrm{~b}$ \\
0.40 & $1.83 \mathrm{a}$ \\
Significance & $* * *$ \\
\hline
\end{tabular}

***Means are significantly different by Tukey's honestly significant difference test at $P \leq 0.001$.

growers rated PLA-SP.A-BR and PLA-SP.A containers lower than PLA-lignin and petroleum-based plastic containers when using the same rating criteria employed in this experiment (Flax et al., 2017). These similarities among ratings may confer additional credibility on the commercial grower participants' ratings reported by Flax et al. (2017). However, our findings in this experiment also suggest that PLA-SP.A-BR and PLA-SP.A containers may have poorer aesthetic quality postproduction than petroleum-based plastic containers, regardless of substrate moisture management practices. Commercial bedding plant producers interested in SP.A-based containers may have to decide whether the utility and improvement in sustainability provided by SP.A-based containers (degradability, biorenewable sourcing, and fertilizer provision) are worth the reduction in the aesthetic quality of these containers compared with petroleum-based plastic and other more durable bioplastics such as PLA-lignin.

Even though our results reveal some possible weaknesses of SP.A-based bioplastic containers, they also indicate the potential to reduce aesthetic decline of these containers through moisture management practices. The aesthetics of PLA-SP.A-BR containers were rated lower than petroleum-plastic containers within VWC treatments; however, their appearance was rated $45 \%$ to $54 \%$ higher when plants were grown at $0.20 \mathrm{~m}^{3} \cdot \mathrm{m}^{-3}$ substrate VWC, compared with $0.40 \mathrm{~m}^{3} \cdot \mathrm{m}^{-3}$ (Tables 6 and 9). This suggests that the postproduction aesthetic quality of SP.A-based containers can be improved by reducing substrate VWC during production. We recommend that bioplastic containers manufactured with materials that enhance degradability and/or provide fertilizer nutrients [e.g., SP.A, BR, and other plant proteins or biomass (Grewell et al., 2014; McCabe et al., 2016; Schrader et al., 2017)] be evaluated to determine if restricting moisture is an effective mean for maintaining the aesthetic quality of containers. In addition, research by others has demonstrated that the addition of colorants to bioplastics containing SP.A or BR can improve the postproduction aesthetics of containers by reducing or masking the blotchy areas seen on the surface of materials without colorant (Schrader, 2016; Schrader et al., 2016). 
Table 8. Irrigation volume (per plant), horizontal wet strength, and compression required to crack containers used to grow zonal geranium (Pelargonium $\times$ hortorum L.H. Bailey 'Pinto Premium Deep Red') in four types of 11.4-cm-diameter bioplastic plant containers and a petroleum-based plastic (control) container filled with soilless substrate amended with $4.2 \mathrm{~kg} \cdot \mathrm{m}^{-3}$ controlled release fertilizer, and maintained at 0.20 or $0.40 \mathrm{~m}^{3} \cdot \mathrm{m}^{-3}$ substrate volumetric water content (VWC). Data were pooled across VWC for each container type.

\begin{tabular}{lccc}
\hline & & \multicolumn{2}{c}{ Horizontal } \\
\cline { 3 - 4 } Container type $^{\mathrm{z}}$ & Irrigation vol $(\mathrm{L})$ & Wet strength $(\mathrm{MPa})$ & Compression to crack $(\mathrm{mm})$ \\
\hline PLA-lignin & $1.43 \mathrm{bc}^{\mathrm{y}}$ & $0.33 \mathrm{a}$ & $38.8 \mathrm{a}$ \\
PLA-SP.A-BR & $1.23 \mathrm{c}$ & $0.01 \mathrm{~d}$ & $25.7 \mathrm{c}$ \\
PLA-SP.A & $1.65 \mathrm{ab}$ & $0.09 \mathrm{c}$ & $34.0 \mathrm{~b}$ \\
PHA-DDGS & $1.94 \mathrm{a}$ & $0.10 \mathrm{c}$ & $42.1 \mathrm{a}$ \\
Petroleum-based plastic & $1.67 \mathrm{ab}$ & $0.16 \mathrm{~b}$ & - $^{\mathrm{x}}$ \\
\hline
\end{tabular}

${ }^{\mathrm{z}}$ Container types are blends of different ratios of bioplastic and biocomposite materials; PLA = polylactic acid; SP.A = soy polymer with adipic anhydride; $\mathrm{BR}=$ a proprietary bio-based filler derived from dried distiller's grains and solubles; PHA = polyhydroxyalkanoates; DDGS = dried distiller's grains and solubles.

${ }^{\mathrm{y}}$ Means within columns that share letters are similar by Tukey's honestly significant difference test at $P \leq$ 0.05 .

${ }^{\mathrm{x}}$ Petroleum-based plastic containers did not crack.

Table 9. Growth index, shoot dry mass (SDM), container vertical wet strength, and container aesthetic quality ratings for zonal geranium (Pelargonium $\times$ hortorum L.H. Bailey 'Pinto Premium Deep Red') grown in four types of 11.4-cm-diameter bioplastic biocontainers and a petroleum-based plastic (control) container filled with soilless substrate amended with $4.2 \mathrm{~kg} \cdot \mathrm{m}^{-3}$ controlled release fertilizer, maintained at 0.20 or $0.40 \mathrm{~m}^{3} \cdot \mathrm{m}^{-3}$ substrate volumetric water content.

\begin{tabular}{|c|c|c|c|}
\hline \multirow[b]{2}{*}{ Container type ${ }^{z}$} & \multicolumn{3}{|c|}{ Substrate volumetric water content $\left(\mathrm{m}^{3} \cdot \mathrm{m}^{-3}\right)$} \\
\hline & 0.20 & 0.40 & Significance $^{y}$ \\
\hline \multicolumn{4}{|l|}{ Growth index ${ }^{x}$} \\
\hline PLA-lignin & $17.8 \mathrm{a}^{\mathrm{w}}$ & $21.1 \mathrm{a}$ & * \\
\hline PLA-SP.A-BR & $11.3 \mathrm{~b}$ & $19.9 \mathrm{a}$ & ** \\
\hline PLA-SP.A & $18.5 \mathrm{a}$ & $21.4 \mathrm{a}$ & NS \\
\hline PHA-DDGS & $16.9 \mathrm{a}$ & $20.1 \mathrm{a}$ & ** \\
\hline Petroleum-based plastic & $18.1 \mathrm{a}$ & $20.8 \mathrm{a}$ & * \\
\hline \multicolumn{4}{|l|}{ SDM $(g)$} \\
\hline PLA-lignin & $21.0 \mathrm{a}$ & $25.0 \mathrm{a}$ & * \\
\hline PLA-SP.A-BR & $9.9 \mathrm{~b}$ & $23.2 \mathrm{a}$ & ** \\
\hline PLA-SP.A & $21.7 \mathrm{a}$ & $24.8 \mathrm{a}$ & NS \\
\hline PHA-DDGS & $20.8 \mathrm{a}$ & $24.5 \mathrm{a}$ & NS \\
\hline Petroleum-based plastic & $21.8 \mathrm{a}$ & $25.5 \mathrm{a}$ & NS \\
\hline \multicolumn{4}{|l|}{ Aesthetic rating ( 1 to 5 scale $)^{\mathrm{v}}$} \\
\hline PLA-lignin & $5.0 \mathrm{a}$ & $5.0 \mathrm{a}$ & NS \\
\hline PLA-SP.A-BR & $2.7 \mathrm{c}$ & $1.5 \mathrm{~d}$ & * \\
\hline PLA-SP.A & $3.9 \mathrm{~b}$ & $3.0 \mathrm{c}$ & NS \\
\hline PHA-DDGS & $4.0 \mathrm{~b}$ & $4.2 \mathrm{~b}$ & NS \\
\hline Petroleum-based plastic & $5.0 \mathrm{a}$ & $5.0 \mathrm{a}$ & NS \\
\hline \multicolumn{4}{|l|}{ Vertical wet strength (MPa) } \\
\hline PLA-lignin & $2.25 \mathrm{a}$ & $2.25 \mathrm{a}$ & NS \\
\hline PLA-SP.A-BR & $0.19 \mathrm{c}$ & $0.06 \mathrm{~d}$ & ** \\
\hline PLA-SP.A & $0.48 \mathrm{~b}$ & $0.33 \mathrm{c}$ & NS \\
\hline PHA-DDGS & $0.49 \mathrm{~b}$ & $0.33 \mathrm{c}$ & * \\
\hline Petroleum-based plastic & $0.40 \mathrm{~b}$ & $0.40 \mathrm{~b}$ & NS \\
\hline \multicolumn{4}{|c|}{ Vertical compression to crack (mm) } \\
\hline PLA-lignin & $11.9 \mathrm{a}$ & $9.8 \mathrm{a}$ & NS \\
\hline PLA-SP.A-BR & $5.8 \mathrm{~b}$ & $3.9 \mathrm{~d}$ & NS \\
\hline PLA-SP.A & $6.2 \mathrm{~b}$ & $5.2 \mathrm{c}$ & NS \\
\hline PHA-DDGS & $12.6 \mathrm{a}$ & $7.1 \mathrm{~b}$ & $* * *$ \\
\hline Petroleum-based plastic & 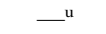 & - & - \\
\hline
\end{tabular}

${ }^{\mathrm{z}}$ Container types are blends of different ratios of bioplastic and biocomposite materials; PLA $=$ polylactic acid; SP.A = soy polymer with adipic anhydride; BR = a proprietary bio-based filler derived from dried distiller's grains and solubles; PHA = polyhydroxyalkanoates; DDGS = dried distiller's grains and solubles.

${ }^{\mathrm{y}}$ Significance of differences among rows by Tukey's honestly significant difference test.

${ }^{\mathrm{x}}$ Growth index $=\{$ plant height $+[($ diameter $1+$ diameter 2$) / 2]\} / 2$.

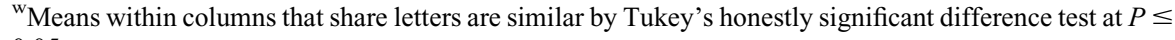
0.05 .

${ }^{\mathrm{v}}$ Ratings are on a 1 to 5 Likert scale; 1 = worst quality, 2 = below average quality, 3 = average quality, $4=$ above average quality, $5=$ best quality.

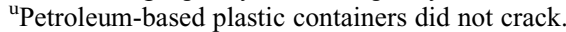

$*, * *, * * *$, ss Nonsignificant or significant at $P \leq 0.05,0.01,0.001$, or Ns, respectively.

Although PLA is biodegradable in soil over relatively long periods of time (1-2 years or more; Grewell et al., 2014) it is et al., 2014). When blended with composites such as lignin, a microbe-resistant polymer found in the cell walls of plants, degradation is reduced in compost conditions when compared with $100 \%$ PLA containers (Schrader et al., 2016). Conversely, the addition of SP.A and/or BR to PLA has been reported to increase the degradability compared with $100 \%$ PLA containers (Kratsch et al., 2015; Schrader et al., 2016). More rapid degradation of these components during crop production may explain the low postproduction strength of PLA-SP.A and PLA-SP.A-BR containers compared with PLA-lignin containers. Another biocontainer research (Evans et al., 2010) reported a range of wet strengths for different biocomposite containers exposed to the environmental and cultural conditions of greenhouse crop production. They reported that rice hull containers, made from a composite of plant fibers and polymer filler much like our PLA-lignin containers, had greater vertical and horizontal strength than their petroleum-based plastic control. Alternatively, the wet strength of OP47 (wheat-starch bioplastic) containers was lower than that of petroleum-based plastic controls (Evans et al., 2010). Our results reflect a similar trend observed among PLA-SP.A-BR containers (Tables 5, 8, and 9), which suggest that higher proportions of readily degradable base materials such as proteins and carbohydrates (including SP.A and BR) may weaken the structural properties of bioplastic biocontainers.

Substrate VWC also affected the strength of some but not all container types that we evaluated. The vertical wet strength of both PLA-SP.A-BR and PHA-DDGS containers used to produce geraniums was reduced when substrate VWC was maintained at $0.40 \mathrm{~m}^{3} \cdot \mathrm{m}^{-3}$ compared with $0.20 \mathrm{~m}^{3} \cdot \mathrm{m}^{-3}$ (Table 9), and the strength of containers used to produce new guinea impatiens decreased with higher VWC (Table 4). Similarly, differences in vertical compression required to crack PLA-SP.A-BR, PLA-SP.A, and PHADDGS containers used to produce new guinea impatiens suggest that container materials become more pliable when plants are grown at higher substrate VWC. Interestingly, fewer differences in vertical compression to break were observed across VWCs for containers used to produce geranium (Table 9); however, the magnitude of differences in means within VWC and across container types suggests that VWC did influence the physical properties of the containers. We do not believe that fewer differences observed among containers used to produce geranium were a function of the difference in taxon, rather that it may be a result of the shorter crop production time of 6 weeks, as opposed to the 7 weeks for new guinea impatiens. These observations affirm our hypothesis that substrate moisture management can affect the functional strength of bioplastic containers, particularly those manufactured with materials such as SP.A or BR.

However, we do not believe that the vertical wet strength of PLA-lignin or durable bioplastic with physical characteristics similar to polyethylene terephthalate, a widely used petroleum-based plastic ( $\mathrm{Lu}$ 
petroleum-plastic containers used to produce new guinea impatiens was influenced by VWC, despite the main effect's significance. Vertical wet strength of PLA-lignin and petroleum-plastic containers used to produce new guinea impatiens differed by only 0.01 $\mathrm{MPa}$ compared with those used to grow geranium at both VWCs. In addition, no differences in strength were observed across VWC and within container type for PLAlignin and petroleum-based plastic containers used to produce geranium (Table 9). Furthermore, we believe the combination of longer production duration and greater total amount of water applied to new guinea impatiens increased the magnitude of VWC effect on vertical wet strength of containers to differ between new guinea impatiens and geranium.

Although reducing substrate VWC can improve aesthetics and structural properties of certain bioplastic containers, reducing the amount of moisture applied affects plant size. Our results agree with other research that has shown that plants grown at a lower substrate VWC were smaller than plants grown at a higher VWC (Alem et al., 2015; Bayer et al., 2013; Litvin et al., 2016). Although the growth index of new guinea impatiens and geranium in our experiment were smaller at $0.20 \mathrm{~m}^{3} \cdot \mathrm{m}^{-3} \mathrm{VWC}$ than at $0.40 \mathrm{~m}^{3} \cdot \mathrm{m}^{-3}$, plants grown at the lower VWC were still of marketable size and had abundant flowers. Based on the lack of differences in WUE, despite difference in growth, our results suggest that bedding plant producers may be able to effectively restrict the plant size of the taxa we used without reducing the efficiency of water applied between 0.20 and $0.40 \mathrm{~m}^{3} \cdot \mathrm{m}^{-3}$ VWC. Ultimately, this may enable producers to grow bedding plants to a target size using specific substrate VWCs, similarly to poinsettia grown by Alem et al. (2015). Screening additional taxa for the tolerance of reduced substrate VWC may be valuable for bedding plant producers seeking nonchemical means of controlling the growth of annual bedding plants. Results from such screenings would also help growers determine which taxa could be grown in degradable and nutrient-providing bioplastic containers, while preserving the appearance and structural integrity of these containers by reducing VWC during greenhouse production.

\section{Conclusions}

Reducing substrate VWC can improve the postproduction aesthetic quality of bioplastic plant containers manufactured with compostable or biodegradable plant protein-based components such as SP.A and BR, but ultimately, these containers may have less aesthetic appeal after greenhouse production than containers made of petroleum-based plastic or durable bioplastics such as PLAlignin. Our results suggest that containers made of PLA-SP.A-BR at the high blend ratio examined in our experiments $(50 / 30 / 20$, respectively) may not be suitable for use in commercial greenhouse crop production. The high percentage of degradable, nutrient-containing materials (50\% SP.A and BR combined) cause them to lose strength and have a less pleasing appearance than other bioplastic container types by the end of plant production. Substrate VWC affects the structural integrity of certain bioplastic container types differently, and containers manufactured with more degradable, nutrientcontaining materials experience a greater loss in strength when grown at a higher substrate VWC. Bioplastic containers that are less degradable, such as those made of PLAlignin, show durability equal to that of petroleum-based plastic containers and maintain their pristine appearance regardless of VWC during plant production. With the increasing variety of bioplastic container types being developed, bedding plant producers have more choices than ever. Those interested in improving the sustainability of their operations by adopting bioplastic containers should select container types with durability, nutrient characteristics, or both that properly align with their goals, crop culture practices, and intended duration of time in production.

\section{Literature Cited}

Alem, P., P.A. Thomas, and M.W. van Iersel. 2015. Use of controlled water deficit to regulate poinsettia stem elongation. HortScience 50:234-239.

Bayer, A., I. Mahbub, M. Chappell, J. Ruter, and M.W. van Iersel. 2013. Water use and growth of Hibiscus acetosella 'Panama Red' grown with a soil moisture sensor controlled irrigation system. HortScience 48:980-987.

Conneway, R., S. Verlinden, A.K. Koeser, M.R. Evans, R. Schnelle, V. Anderson, and J.R. Stewart. 2015. Use of alternative containers for long- and short-term greenhouse crop production. HortTechnology 25:26-34.

Currey, C., K.G. McCabe, J. Schrader, W. Graves, J. Behrens, and D. Grewell. 2015. Biocontainers 2.0. GrowerTalks 79(5):74-78.

Currey, C., J. Schrader, K. McCabe, and W.R. Graves. 2013. Bioplastics for greenhouses. Soy what? GrowerTalks 77(8):70-74.

Currey, C., J. Schrader, K. McCabe, W. Graves, D. Grewell, G. Srinivasan, and S. Madbouly. 2014. Soy containers: Growing promise, growing plants. GrowerTalks 77(10):60-65.

Evans, M.R. and D. Hensley. 2004. Plant growth in plastic, peat, and processed poultry feather fiber growing containers. HortScience 39:10121014.

Evans, M.R. and D. Karcher. 2004. Properties of plastic, peat and processed poultry feather growing containers. HortScience 39:1008-1011.

Evans, M.R., M. Taylor, and J. Kuehny. 2010. Physical properties of biocontainers for greenhouse crops production. HortTechnology 20:549-555.

Flax, N.J., C.J. Currey, J.A. Schrader, D. Grewell, and W.R. Graves. 2017. Commercial greenhouse growers can produce high-quality bedding plants in bioplastic-based biocontainers. HortTechnology 27:472-481.

Grewell, D., G. Srinivasan, J. Schrader, W. Graves, and M. Kessler. 2014. Sustainable materials for horticultural application. Plast. Eng. 70:44-52.

Hall, C.R., B.L. Campbell, B.K. Behe, C. Yue, R.G. Lopez, and J.H. Dennis. 2010. The appeal of biodegradable packaging to floral consumers. HortScience 45:583-591.

Haver, D.L. and U.K. Schuch. 1996. Production and postproduction performance of two New
Guinea Impatiens cultivars grown with controlledrelease fertilizer and no leaching. J. Amer. Soc. Hort. Sci. 121:820-825.

Koeser, A.K., G. Kling, C. Miller, and D. Warnock. 2013. Compatibility of biocontainers in commercial greenhouse crop production. HortTechnology 23:149-156.

Koeser, A.K., S.T. Lovell, A.C. Petri, R.G. Brumfield, and J.R. Stewart. 2014. Biocontainer use in Petunia $\times$ hybrida greenhouse production system: A cradle-to-gate carbon footprint assessment of secondary impacts. HortScience 49:265-271.

Kratsch, H.A., J.A. Schrader, K.G. McCabe, G. Srinivasan, D. Grewell, and W.R. Graves. 2015. Performance and biodegradation in soil of novel horticulture containers made from bioplastics and biocomposites. HortTechnology 25:119-131.

Krug, B.A., A. Papineau, and J.S. Owen. 2014. Comparing controlled release fertilizers to constant liquid feed for zonal geranium production. Acta Hort. 1034:525-530.

Kuehny, J.S., M. Taylor, and M.R. Evans. 2011. Greenhouse and landscape performance of bedding plants in biocontainers. HortTechnology 21:155-161.

Litvin, A.G., M.W. van Iersel, and A. Malladi. 2016. Drought stress reduces stem elongation and alters gibberellin-related gene expression during vegetative grown of tomato. J. Amer. Soc. Hort. Sci. 141:591-597.

Lopez, R.G. and D. Camberato. 2011. Growth and development of 'Eckespoint Classic Red' poinsettia in biodegradable and compostable containers. HortTechnology 21:419-423.

Lu, H., S.A. Madbouly, J.A. Schrader, G. Srinivasan, K.G. McCabe, D. Grewell, M.R. Kessler, and W.R. Graves. 2014. Biodegradation behavior of poly(lactic acid) (PLA/distiller's dried grains with solubles (DDGS) composites. ACS Sustain. Chem. Eng 2:2699-2706.

McCabe, K.G., J.A. Schrader, C.J. Currey, D. Grewell, and W.R. Graves. 2016. Soycomposite biocontainers allow for reduced fertilizer inputs during container-crop production. HortScience 51:927-934.

McCabe, K.G., J.A. Schrader, S. Madbouly, D. Grewell, and W.R. Graves. 2014. Evaluation of biopolymer-coated fiber containers for container-grown plants. HortTechnology 24: 439-448.

Montalbo-Lomboy, M., Schrader, J.A. and D. Grewell. 2016. Cradle-to-gate life cycle assessment of bioplastic horticulture containers and comparison to standard petroleum-plastic containers. In: J.A. Schrader, H.A. Kratsch, and W.R. Graves (eds.). Bioplastic containercropping systems: Green technology for the green industry. Sustain. Hort. Res. Consortium, Ames, IA.

Nambuthiri, S., A. Fulcher, A.K. Koeser, R. Geneve, and G. Niu. 2015. Moving towards sustainability with alternative containers for greenhouse and nursery crop production: A review and research update. HortTechnology 25:8-16.

Nemali, K. and M. van Iersel. 2006. An automated system for controlling drought stress and irrigation in potted plants. Scientia Hort. 110:292297.

Schrader, J.A. 2013Report on the annual consumption of plastics for specialty-crop containers in the United States. Iowa State Univ. Bioplastics Res. 5 Jan. 2017. <http://www.public.iastate.edu/ $\sim$ bioplastic/Supplementary/AnnualPlastic.html $>$.

Schrader, J.A. 2016. Status of bioplastic container cropping systems technology: Aug. 2016. In: J.A. Schrader, H.A. Kratsch, and W.R. Graves (eds.). Bioplastic container cropping systems: 
Green technology for the green industry. Sustain. Hort. Res. Consortium, Ames, IA.

Schrader, J.A., K.G. McCabe, D. Grewell, and W.R. Graves. 2017. Bioplastics and biocomposites for sustainable horticulture containers: Performance and biodegradation in home compost. Acta Hort. 1170:1101-1108.

Schrader, J.A., K.G. McCabe, H.A. Kratsch, and A. Koeser. 2016. Degradability of bioplastic containers in soil and compost. In: J.A. Schrader,
H.A. Kratsch, and W.R. Graves (eds.). Bioplastic container cropping systems: Green technology for the green industry. Sustain. Hort. Res. Consortium, Ames, IA.

Schrader, J.A., K.G. McCabe, G. Srinivasan, K. Haubrich, D. Grewell, S. Madbouly, and W.R. Graves. 2015. Development and evaluation of bioplastic containers for sustainable greenhouse and nursery production. Acta Hort. 1104:79-88.
Schrader, J.A., G. Srinivasan, D. Grewell, K.G. McCabe, and W.R. Graves. 2013. Fertilizer effects of soy-plastic containers during crop production and transplant establishment. HortScience 48:724-773.

U.S. Department of Agriculture. 2015. Census of horticultural specialties 2014. 12 Jan. 2017. $<$ http://www.agcensus.usda.gov/Publications/ 2012/Online_Resources/Census_of_Horticulture_ Specialties/HORTIC.pdf>. 